\title{
MJN FROM AGONY TO ADAPTATION: JOURNEY OF MOTHERS AS PRIMARY CAREGIVER FOR THEIR CHILDREN WITH PDA
}

\author{
Mary Grace B. Baron, Alain Kenneth S. Ragay \\ R.N, MSN- Nurse Sonographer, MyHealth Clinic, Cebu City \\ RN, MAN-Faculty, Cebu Normal University \\ *Corresponding Author's Email: marygrace_baron@yahoo.com
}

\begin{abstract}
A mother's love for her child knows no limit. Her role as a primary caregiver depicts her genuine love to her child when it comes to health-related issues especially the involvement of a vital organ such as the heart. This situation is alarming to the mother since the child would manifest dyspnea and a murmur called "Gibson's murmur" which may be heard using a stethoscope. This type of Congenital Heart Defect (CHD) is called Patent Ductus Arteriosus (PDA). It is the sixth most common CHD and unsuccessful closure of PDA appeared to be dangerous which raised a mortality rate of $70 \%$ in contrast with $11 \%$ infants who underwent an effective closure. This study utilized the qualitative phenomenological design particularly Husserlian phenomenology. The research was conducted in Cebu, Philippines. Purposive and snowball sampling technique were utilized by means of referral by a pediatric cardiologist. There were 10 Key Informants and their real names were not used in observance of their privacy and confidentiality. Prior to the conduct of the study, the researcher underwent bracketing of ideas, opinions and biases to prevent undesirable effects in the research process. Before the actual interview, the tool was pilot tested to three key informants with a child who underwent operation for the treatment of CHD. The study used a researcher-made, semi-structured interview guide and open-ended questions were utilized. One on one interview was implemented by the researcher in their preferred place. Consent was given voluntarily by the key informants and without coercion. The researcher followed the steps of analysis as proposed by Colaizzi. A scheduled follow-up appointment was made by the researcher and key informants for the validation of results. The clustered themes were: (1) Agony: a struggle before operation; Subtheme 1: Fear of the unknown; Sub-theme 2: Sadness and Denial; Subtheme 3: Financial challenge: a difficult task; Sub-theme 4: Caring challenges; (2) Ambivalence: a mixed feelings during operation; (3) Alleviation; a mother's relief after operation; (4) Altruism: a selfless love; and (5) Adaptation: internal and external support; Sub-theme 1: Prayer: the powerful key to coping; Sub-theme 2: Financial support; and Sub-theme 3: Social support.
\end{abstract}

Keywords: PDA, Altruism, Adaptation, Descriptive Phenomenology, Qualitative Research, Colaizzi

\section{INTRODUCTION}

\section{Background and Rationale of the Study}

A mother expresses great concern for her child when it comes to health-related issues especially the involvement of a vital organ such as the heart. The main function of the heart is to pump blood throughout the body organs. However, the presence of heart problems where some are acquired congenitally, affect the circulatory function of the heart. This would result in heart pumping extra amount of blood to the lungs, making the heart and lungs work harder and thus would lead to lung congestion (American Heart Association, 2018). This situation is alarming to the mother since the child would manifest dyspnea, full and bounding radial pulse on exertion and a characteristic machinery type of murmur called "Gibson's murmur" which may be heard using a stethoscope. This type of Congenital Heart Defect (CHD) is called Patent Ductus Arteriosus (PDA) (Leifer, 2015).

The sixth most common congenital heart defect is PDA, recorded for $5 \%$ to $10 \%$ of cases, without including preterm infants. It is a complex and common problem in preterm neonates, accounting in $60 \%$ of infants younger 
than 28 weeks of gestation (Rathke et al., 2014). PDA is accounted to have an approximation of one-third of babies weigh 501-1500 g and nearly half of infants weighing $<1000 \mathrm{gm}$ in need of medical management to treat symptomatic ductal patency (Engür, Deveci \& Türkmen, 2015).

The ductus arteriosus is essential in fetal life which permits blood to bypass the lungs while maintaining the systemic blood circulation. The ductus typically closes in infants after birth, however in preterm infants, it may remain open (Wei et al., 2015). Unsuccessful closure of PDA appeared to be dangerous which raised a mortality rate of $70 \%$ in contrast with $11 \%$ infants who underwent an effective closure in a single-centre retrospective study (Kang et al., 2012).

Nowadays, there are medical-surgical management options for the treatment of PDA. PDA correction may include: Indomethacin drug therapy that lead to PDA closure. Heart surgery is done to all newborn full-term infants with PDA for the prevention of embolus formation, congestive heart failure (CHF) and other factors that lead to complications. The thoracotomy surgery is conducted for the purpose of ligating the ductus arteriosus. The Video-Assisted Thoracoscopic Surgery (VATS) technique removed the making of large chest incision upon ligating the ductus arteriosus. The option for nonsurgical treatment includes coil insertion to close the PDA, which is performed in a cardiac catheterization lab (Leifer, 2015).

Despite the surgical options available in recent cardiovascular surgery, mothers still encountered obstacles in the process of decision-making prior to the plan of heart surgery of the child. Shu-Fan, Pei-Fan \& Kai-Sheng (2007), found that mothers including their families faced a stressful situation in the decisionmaking procedure of the child's cardiac surgery. It also revealed that the mothers experienced psychological distress due to the related matter. Furthermore, Re, Dean \& Menahem (2013) reported that almost all of the mothers experienced symptoms of acute stress due to the child's diagnosis and the need for the child to undergo cardiac surgery. Moreover, Franich-Ray et al. (2013) reported that majority of the mothers whose less than three months old child underwent cardiac surgery manifested some symptoms of trauma. Even though the child's surgery was successful, mothers still showed a dissociation symptom which is related to Acute Stress Disorder, considering that Filipino mothers are the primary caregivers which are anticipated to provide care for the children and to manage the home (Alampay \& Jocson, 2011). Sabzevari et al., (2016) found out that mothers must allocate more time when her child becomes sick. The nature of accomplishing their familial, professional and social roles may be affected by the issues in health and the disease outcome that can result to the appearance of psychological problems among mother. It showed that the mothers of CHD children allowed the existence of several obstacles in their child's care. Lázaro \& Pondé,. (2017) noted that mothers dealt with a continued and often unpleasant experience in looking for their child's treatment. Moreover, Vallejos (2015) reported that a mother with a CHD child strive with continuous feelings of isolation, insecurity and stress.

However, Jordan et al. (2014) stressed that most mothers experienced a positive relationship with the infant after cardiac surgery. Bruce et al. (2014) also empasized that mothers perceived to be more supported upon receiving family-centered and person-centered care and because of such, more mothers would probably adapt to the demands of parenting a CHD child. In addition, Mellow (2014) exemplified the capacity of mothers to recover quickly from adversity and were able to confirm the essence of motherhood emerging a positive relationship and strong tie with the infants.

There were few studies about Patent Ductus Arteriosus (PDA) in the Philippines (Cheng, Ortiz \& Angtuaco, 2013; Ofiaza et al., 2008). However, there was no study about the lived experience of a mother as primary caregiver of her child with PDA in the Philippines. For this reason, the researcher was interested to explore the lived experience of mothers in caring for their children who underwent medicalsurgical management for PDA. This study utilized qualitative phenomenological design particularly Husserlian phenomenology since the researcher was interested in exploring the lived experience of mothers as primary caregivers in caring for their children who underwent treatment for PDA.

\section{Statement of the Problem}

The study aims to explore the lived experience of mothers as primary caregivers in caring for their children who underwent management for Patent Ductus Arteriosus (PDA).

\section{Significance of the study}

The result of the study will provide deep understanding on the mothers' lived experience in 
caring for their children with such disease. In addition, this research study will be significant and beneficial to the following:

Medical - Surgical Nurses. They realize their important roles as nurse educators and provide information about PDA to the society. They explain to the mothers on the essence of PDA operation in their child's life. They value the essence of encouraging the mothers to be strong and not lose hope in the treatment of their children with PDA.

Mothers of Child with Patent Ductus Arteriosus. This study recognizes their hardwork and perseverance in caring for their children with PDA. The altruistic love they expressed to their children will be shown in this study.

Community. This study educates them on the shared role that they need to contribute in caring for a child with PDA. In that way, they will comprehend that helping the mother will be an impact in reducing the burden of the mother.

Future Researchers. The ideas presented in the study also serves as a guide for future researchers who might be interested to pursue a study which is exactly similar to this study.

\section{Review of Related Literature and Studies}

This chapter includes related literature and previous studies relative to a type of Congenital Heart Defect (CHD) called Patent Ductus Arteriosus (PDA).

Before a child's birth, the blood of a fetus does not necessarily go to the lungs for it to be oxygenated. The hole that enables the blood to skip the lungs' circulation is called ductus arteriosus. During the child's birth, this hole supposedly should close, and the blood must be oxygenated in the lungs. In the event that the ductus arteriosus remains to be open or patent, the blood may skip this essential circulation step. Thus, the patent hole is called Patent Ductus Arteriosus (PDA) (American Heart Association, 2018). PDA is defined as failure of the ductus arteriosus to close within 72 hours after birth (Bhatia \& Dice, 2007). In PDA, the recirculation of oxygenated blood in the lungs causes the overburdening in the pulmonary circulation and thus makes the heart pump harder (Leifer, 2015).

The reported incident of PDA in term neonates is only 1 in 2,000 births, accounting for 5\%-10\% of all congenital heart disease (Lumsden, Smith \& Wittkowski, 2011). The incidence of PDA in preterm neonates is far greater, with reports ranging from $20 \%$ $60 \%$. The increased incident of PDA in the preterm infant is related to immaturity due to the lack of normal closure mechanism. Specifically, PDA is present in $80 \%$ of infants weighing less than $1,200 \mathrm{~g}$ at birth, compared to $40 \%$ of infants weighing less than $2,000 \mathrm{~g}$ at birth. Furthermore, symptomatic PDA is present in $48 \%$ of infants with a birth weight of less than $1,000 \mathrm{~g}$ (Bhatia\& Dice, 2007; Barreto et al., 2016).

PDA is considered the sixth most common CHD, recorded for $5 \%$ to $10 \%$ of cases, without including preterm infants. It is a complex and common problem in preterm neonates, accounting in $60 \%$ of infants younger than 28 weeks age of gestation (Rathke et al., 2014). The ductus typically closes in full term infants after birth, however in preterm infants, it may remain open (Wei et al., 2015). Unsuccessful closure of PDA appeared to be dangerous which raised a mortality rate of $70 \%$ in contrast with $11 \%$ infants who underwent an effective closure in a single-centre retrospective study (Kang et al.,2012).

A child with symptomatic PDA would manifest the clinical manifestations of tachycardia, cardiomegaly, and poor weight gain (Bhatia \& Dice 2007). Furthermore, as a child with PDA grows, dyspnea is experienced, the radial pulse becomes full and bounding during exertion and a characteristic machinery type of murmur may be heard using a stethoscope (Leifer, 2015).

Laboratory testing and diagnostic test further enhance the clinical picture of PDA. Either left or right ventricular hypertrophy or both may be revealed with an electrocardiogram (ECG), however ECG does not provide any information on ductal-dependent lesions. Moreover, cardiomegaly and increased pulmonary markings can be seen with chest radiography. Additionally, B-type natriuretic peptide (BNP) levels may be useful. Some studies have reported specificity of $73 \%$ and sensitivity of $93 \%$ using a cutoff value of $70 \mathrm{pg} / \mathrm{ml}$. BNP measurement does not replace echocardiogram as a method of diagnosis, but rather gives additional information. Furthermore, echocardiography is the gold standard for diagnosis. Two-dimensional echocardiography will provide anatomic information about the diameter, length, and shape of the ductus. Doppler flow will provide information on the ductal shunt magnitude and patterns (Bhatia \& Dice, 2007). Accurate diagnosis of patent ductus arteriosus requires echocardiography. Together with Doppler and colour Doppler, echocardiography allows assessment of the potency, ductus arteriosus 
diameter and shunt direction (Yapakçi et al., 2014).

In the field of modern science and technology, medical-surgical management options are available for the PDA treatment. PDA correction may include the use of Indomethacin drug therapy that lead to PDA closure (Leifer, 2015). Indomethacin administered via intravenous showed a reduction of cases in PDA and the occurence of intraventricular hemorrhage grade 2 and 3 without any untoward adverse reactions (Jannatdoust et al., 2014).

When the PDA did not close after medical treatment or when there is contraindication of prostaglandin synthetase inhibitor usage, surgical ligation may be preferred (Kang et al., 2012). Heart surgery is done to all newborn full-term infants with PDA for the prevention of embolus formation, congestive heart failure (CHF) and other factors that lead to complications. The thoracotomy surgery will be performed for the purpose of ligating the ductus arteriosus. Other surgery option includes the usage of VATS technique which removes the mandatory way of making large chest incision upon ligating the ductus arteriosus (Leifer, 2015).

Despite the surgical options available in recent cardiovascular surgery, mothers still encountered obstacles in the process of decision-making prior to the plan of heart surgery of the child. Lan, Mu \& Hsieh (2007), argued that mothers including their families faced a stressful situation in the decision-making procedure of the child's cardiac surgery. Furthermore, Re et al. (2013) reported that almost all of the mothers experienced symptoms of acute stress due to the child's diagnosis and the need for cardiac surgery. Moreover, Franich-Ray et al. (2013) noted that majority of the mothers who allowed their less than three months old child to undergo cardiac surgery manifested some symptoms of trauma. Even though the child's surgery was successful, mothers still showed a dissociation symptom which is related to Acute Stress Disorder.

Although the mothers encountered stressful situations in making decision in relation to the surgery, cardiac surgery is still proven a good choice for PDA closure. Kang et al. (2012) reported that PDA ligation in preterm babies showed a higher rate in neonatal morbidity but lower rate in complication and neonatal mortality. Furthermore, a study exhibited that the VATS technique in PDA surgery reduced the adverse effects, complications and mortality rate (Esfahanizadeh et al., 2017).
The option for nonsurgical treatment includes coil insertion to close the PDA, which is performed in a cardiac catheterization lab (Leifer, 2015). Transcatheter PDA closure evolved to be the common treatment in the neonatal period of the children (Amoozgar et al., 2016). Jin et al. (2015) reported that excellent occlusion rates with low complication rates were achieved with all devices regardless of PDA types. More patients with PDA can be treated with transcatheter closure both safely and efficiently. Rathke, Menezes \& Filho (2014) found out that percutaneous occlusion of PDA was effective and safe in several cases. A specific attention to technical details and clinical features is necessary to be successful in the procedure.

Behjati-Ardakani et al. (2013) reported that the longterm results of transcatheter closure of PDA using Amplatzer duct occluder suggested a safe and effective treatment in infants less than 1 year of age. Azhar, Abd ElAzim \& Habib (2009) proved that transcatheter occlusion of PDA is an effective and safe alternative to surgery. Dutta et al. (2008) emphasized that thoracoscopic surgery and coil insertion are effective treatment options for patent ductus arteriosus, although coil occlusion is associated with shorter procedure time, shorter hospital stays, and less pain.

Despite the surgical and non-surgical options to treat a child's PDA, mothers still experienced being stressed of their child's condition. Lázaro \& Pondé (2017) expressed that mothers deal with a continued and often unpleasant experience in looking for their child's treatment. The professionals in the health sector need to help the mothers to be confident in caring for their child and build a stronger mother-infant connection. They also aid the mothers to manage and adjust in the child's actual treatment method. Furthermore, Vallejos (2015) emphasized that the mother may have an advantage from social support, psychological support and the multidisciplinary managements of the child's healthcare team.

Despite the challenging experiences, other studies reported that mothers experienced a positive attitude towards caring for her child with such disease due to the support she received. Bruce, Lilja \& Sundin (2014) revealed that the mothers having a CHD child defined support as receiving assistance to obtain their desires and needs. Furthermore, mothers perceived to be more supported upon receiving family-centered and personcentered care and because of such, more mothers would probably adapt to the demands of parenting a CHD child. 
Moreover, Jordan et al. (2014) found out that most mothers experienced a positive relationship with the infant after cardiac surgery, but a quarter of the mothers had a problem in having a strong emotional bonding with the infant. In addition, Mellow (2014) exemplified the capacity of mothers to recover quickly from adversity and encountered personal development and were able to confirm the essence of motherhood and thus emerge a positive relationship and strong tie with the infants.

Despite the studies about the incidence of PDA in the children, their mothers have learned to adapt the situations and conducted ways to address the caregiving procedures to their children during the occurrence of symptoms.

\section{METHODOLOGY}

\section{Research Design}

This research utilized the Qualitative Husserlian Phenomenologic design to explore the lived experience of mothers in caring for their children who underwent management for Patent Ductus Arteriosus (PDA). Descriptive phenomenology was applied here (Husserl, 1978) to describe the human experience. In descriptive phase researchers comprehend and describe the phenomenon (Polit \& Beck, 2010).

\section{Research Locale}

The study was conducted in Cebu, Philippines.
Cebu provides a state-of-the-art technology in terms of cardiovascular medicine and surgery. According to the Vital Statistics Report on Deaths, there were 9 deaths of Patent Ductus Arteriosus (PDA) in the Philippines in 2004 (Philippine Statistics Authority, 2004). In the surveillance of Philippine General Hospital from 20012010, PDA is the third most common birth defect with a total of 672 cases in occurrence per 10,000 admissions (David-Padilla et al., 2011). Moreover, congenital malformation of the heart is the fourth leading cause of death in the Philippines in 2010 (Department of Health, 2010).

\section{Research Key Informants (KIs) and Sampling Technique}

Purposive and Snowball sampling technique were utilized by means of referral by a pediatric cardiologist. The key informants of the study followed an inclusion criterion of: (a) mothers who are primary caregivers of their child with Patent Ductus Arteriosus (PDA) who underwent management, (b) mothers who can communicate without cognitive impairment and (c) mothers voluntarily consent to be a key informant. The obtained data was saturated up to 10 KIs. Pseudonames were assigned by the researcher for the key informants for privacy and confidentiality. Mothers with cognitive impairment and unable to give voluntary consent were excluded from the study. The key informants' profile is reflected in Table 1.

Table 1: Profile of Key Informants

\begin{tabular}{|c|c|c|c|c|c|c|c|c|c|}
\hline $\begin{array}{c}\text { Pseudo } \\
\text { names }\end{array}$ & $\begin{array}{c}\text { Age of } \\
\text { Mother }\end{array}$ & $\begin{array}{c}\text { Civil } \\
\text { Status }\end{array}$ & Occupation & $\begin{array}{c}\text { Educational } \\
\text { Attainment }\end{array}$ & $\begin{array}{c}\text { Number } \\
\text { of } \\
\text { children }\end{array}$ & $\begin{array}{c}\text { PDA } \\
\text { Child }\end{array}$ & $\begin{array}{c}\text { Child's } \\
\text { present } \\
\text { age }\end{array}$ & $\begin{array}{c}\text { Age of the } \\
\text { child } \\
\text { diagnosed } \\
\text { with PDA }\end{array}$ & $\begin{array}{c}\text { Age of the } \\
\text { child } \\
\text { during } \\
\text { operation }\end{array}$ \\
\hline Alice & $\begin{array}{c}39 \text { years } \\
\text { old }\end{array}$ & Married & $\begin{array}{c}\text { Medical } \\
\text { Secretary }\end{array}$ & $\begin{array}{c}\text { Vocational } \\
\text { Course }\end{array}$ & 4 & $4^{\text {th }}$ child & $\begin{array}{c}1 \text { year and } \\
7 \text { months } \\
\text { old }\end{array}$ & $\begin{array}{c}3 \text { months old } \\
11 \text { months } \\
\text { old }\end{array}$ \\
\hline Veronica & $\begin{array}{c}42 \text { years } \\
\text { old }\end{array}$ & Live-In & Housewife & $\begin{array}{c}\text { Elementary } \\
\text { Level }\end{array}$ & 7 & $7^{\text {th }}$ child & $\begin{array}{c}4 \text { years } \\
\text { old }\end{array}$ & 1 year old & 3 years old \\
\hline Amanda & $\begin{array}{c}41 \text { years } \\
\text { old }\end{array}$ & Married & Housewife & $\begin{array}{c}\text { College } \\
\text { Graduate }\end{array}$ & 3 & $1^{\text {st } \text { child }}$ & $\begin{array}{c}11 \text { years } \\
\text { old }\end{array}$ & 6 months old & 1 year old \\
\hline Michelle & $\begin{array}{c}27 \text { years } \\
\text { old }\end{array}$ & Live-In & Housewife & $\begin{array}{c}\text { High School } \\
\text { Graduate }\end{array}$ & 2 & $1^{\text {st } \text { child }}$ & 6 years \\
old
\end{tabular}




\section{Research Instrument}

The study used a researcher-made, semi-structured interview guide. Open-ended questions were utilized by mothers whose child had Patent Ductus Arteriosus (PDA) to elaborate their lived experiences. The research instrument consisted with warm up, transition, main, follow-up and wrap-up questions. Interview guide had an English and Cebuano translation and was validated by a language expert. Before the actual interview, the tool was pilot tested to three key informants with a child who underwent operation for the treatment of Congenital Heart Defect (CHD).

\section{Data-gathering Procedure}

Prior to the conduct of the study, the researcher underwent bracketing of ideas, opinions and biases to prevent undesirable effects in the research process. One on one interview was implemented by the researcher in different locations that were preferred by the KIs. There were 6 KIs that were interviewed in their houses, 3 KIs at the mall and 1 key informant in the doctor's clinic. The interview took place from December 2017 to January 2018. Consent was given voluntarily by the key informants and without coercion. KIs signed the consent voluntarily as an indication of full participation in the study. With the KIs' consent, audio was recorded, and field notes were utilized to supplement narrative details. The interview lasted for 30 minutes to each key informant. A debriefing session was done after the interview by means of psychological and emotional support to the key informants to ensure that there will be no negative emotions felt after the interview. Encryption was utilized to protect and secure the recorded audio and other research data. The gathered data was safely secured.

\section{DataAnalysis}

The Licensed Nvivo 11 Pro qualitative data analysis software was used in this research. The data interpretation was classified in accordance to their responses utilizing Colaizzi's method of data analysis (Morrow, Rodriguez \& King, 2015).

First step is familiarization. The researcher familiarizes him or herself with the data by reading through all the participant accounts several times. In this step, the researcher reads all the KI's descriptions in order to be familiar with the data. The researcher listens to the recorded interview many times before the transcription of data. Transcriptions were done within 48 hours. The verbatim responses of the KIs was then translated into English and the translation was validated by a language expert.

Second step is identifying significant statements. The researcher identifies all statements in the accounts that are of direct relevance to the phenomenon under investigation. In this step, the researcher extracts the sentences or phrases that are directly related to the investigated phenomenon.

Third step is formulating meanings. The researcher identifies meanings pertinent to the phenomenon that arises from a careful consideration of the significant statements. The researcher must reflexively "bracket" his or her pre-suppositions to stick closely to the experienced phenomenon. In this step, the researcher explores the meaning of every significant statements to state formulated meanings. The researcher follows to bracket her ideas in order to prevent undesirable effects in the research.

Fourth step is clustering themes. The researcher clusters the identified meanings into themes that are common across all accounts. Again bracketing of ideas is crucial to avoid any potential influence in the phenomenon. In this step, the researcher arranges the formulated meanings into themes. Again, the researcher brackets her ideas to prevent undesirable results in the study.

Fifth step is developing an exhaustive description. The researcher writes a full and inclusive description of the phenomenon, incorporating all the themes produced in the fourth step. In this step, the researcher integrates all the themes and makes a comprehensive description of the phenomenon.

Sixth step is producing the fundamental structure. The researcher condenses the exhaustive description down to a short, dense statement that captures just those aspects deemed to be essential to the structure of the phenomenon. In this step, the researcher made a concise exhaustive description to convey the essential part of the phenomenon.

The seventh and final step is seeking verification of the fundamental structure. The researcher returns the fundamental structure statement to all participants to ask whether it captures their experience. In this last step, the researcher schedules a follow-up appointment with each key informant for the purpose of validating the essence of the phenomenon.

\section{Role of the Investigator}

The investigator is the interviewer and ensured her 
availability throughout the scheduled time for interview and protect clients' freedom and rights. The researcher asks consent from the key informants to allow their audio to be recorded in the interview for future reference. The investigator analyzed, gathered and transcribed the key informants' narratives from the audio-taped interviews.

\section{Method of Verification}

In Colaizzi's process for phenomenological data analysis, validation of the results was conducted from the research key informants to contrast the descriptive results of the researcher in accordance to their experiences (Shosha, 2012). Thus, a scheduled follow-up appointment was made by the researcher and key informants for the validation of results on March 2018. Any alterations of the result and additional information provided by the key informants was honored in the final description to ensure that the intended meaning is conveyed appropriately.

\section{Ethical Consideration}

This study complied the ERC compliance protocol in Cebu Normal University. KI's signed the consent voluntarily as an indication of full participation in the study. All the KIs of this study were meticulously oriented and were notified regarding the purpose and importance of the study. All KIs were reassured that their names were not used under any circumstances and that all details were held with utmost confidentiality. There was no element of force, fraud, deceit, duress, ulterior form of constraint or coercion to let the key informant participate in this research. All the data were completely removed in all storage drives after the study was accomplished.

\section{RESULTS AND DISCUSSION}

The final purposive sample composed of 10 mothers who are primary caregivers in caring for their children with Patent Ductus Arteriosus (PDA). After data analysis, there were 571 significant statements (SS) of mothers' lived experience that were determined and 22 formulated meanings (FMs) were stated. The formulated meanings were clustered and gathered around 13 themes (T) and finally 5 clustered themes (CTs). The tabulated responses including all the significant statements, formulated meanings, themes and clustered were recorded.

The creation of five clustered themes were presented after the data analysis using Colaizzi's method. The five clustered themes were (1) Agony: a struggle before operation; Sub-theme 1: Fear of the unknown; Sub-theme 2: Denial and Sadness; Sub-theme 3: Financial challenge: a difficult task: Sub-theme 4: Caring challenges; (2) Ambivalence: a mixed feeling during operation; (3)
Alleviation: a mother's relief after operation; (4) Altruism: a selfless love; (5) Adaptation: internal and external support; Sub-theme 1: Prayer: a powerful key to coping; Sub-theme 2: Financial support; and Sub-theme 3: Social support.

The word cloud of written responses was created by utilizing the Licensed Nvivo 11 Pro qualitative data analysis software. The said software would generate a reflection of the frequent words mentioned by the key informants. The bigger the words, the more it was repeatedly mentioned. These words were used as a guide in the formulation of clustered themes in this descriptive study. The Word Cloud is seen in Figure 1.

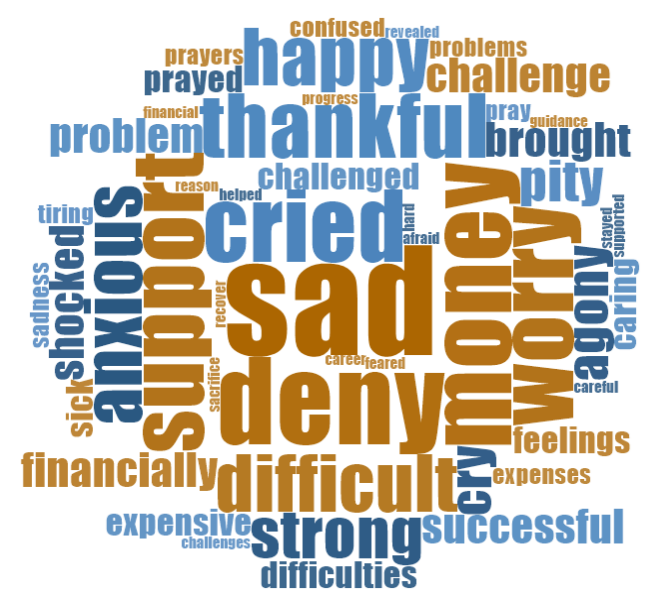

\section{Figure 1: Word Cloud}

\section{Clustered Theme 1: Agony: a struggle before operation}

The mother's experienced an intense pain of mind or body called Agony (Merriam-Webster Dictionary, 2018). All of the KIs verbalized that they experienced agony before their child's operation. All the mothers experienced fear upon seeing an abnormal manifestation of their children before the diagnosis of Patent Ductus Arteriosus (PDA). In relation to their fear, they sought for consultation with a doctor and then was referred to a pediatric cardiologist for further assessment. The specialized doctor then performed echocardiography as basis for his diagnosis. Accurate diagnosis of patent ductus arteriosus requires echocardiography (Yapakçi et al., 2014). Echocardiography is the gold standard for diagnosis (Dice \& Bhatia, 2007). After the diagnostic test, all the mothers were sad of their children's defect and 8 (eight) mothers were in denial of their children's PDA. All mothers suffered from tension at the time of 
diagnosis which affected them during all the stages of treatment and care, not only physically but also mentally (Sabzevari et al., 2016). All the mothers verbalized that they had financial difficulty as the cost of operation was expensive. Cardiac involvement brings with a number of needs for specialized care that mothers and their babies will have to live and this includes administering medications, hospitalizations and surgeries, changing daily life and care of this mother with the baby in the expectations of recovery of the child (Lázaro, C.P. \& Pondé).

\section{Sub-theme 1: Fear of the unknown}

All the mothers compared their children with other kids and observed an abnormal characteristic. Due to this feeling, fear of the unknown emerged into the mind of the mothers. Furthermore, 7 out of 10 mothers noticed a poor growth development of their children. According to the mothers:

SS34: "Unya ang bata kay gamay iyang development, iyang pagtubo ug lahi ra sa normal nga bata." [The child had a poor development; his growth is different from a normal child.]

Ss 46: "Kani jud siya kay walo ra jud siya ka buwan unya gamay jud pagkatao." [She was only 8 months and was very small as an infant.]

SS94: "Maka ingun ka ug panit ug bukog nga nagatiman sa bata." [You can say that you care for a skinny and bony child.]

SS247: "Gamay lang pagkabata kana gani daut jud pagkabata." [She was small and thin as a child.]

SS321: "Ako nakita sa akong anak kay wala siya mudako ug daut jud siya." [I saw my child's poor growth development and was also thin.]

SS409: "Ako nabantayan niya kay gamayon siya pagkabata ug wala nitubo ba." [I noticed that my child was small and had a poor growth development.]

SS532: "Maskin sige siya ug kaon kay daut jud siya." [Though she eats regularly, she was still small.]

Moreover, 6 out of 10 mothers verbalized that their children experienced shortness of breath.

SS6: "Ang akong anak kay maglisod gud ug ginhawa." [My child had difficulty in breathing.]

SS48: “...dili naman siya kaginhawa." [...the child couldn't breathe anymore anymore.]

SS189: "Tapos ako nakita kay kutasan..." [I noticed in him that he always experienced shortness of breath...]

SS265: “...unya mag-apas gud siya sa iyang ginhawa kun naa miy lakaw." [...she had shortness of breath everytime we went out.]

SS325: "Musamot iyang hangak kun ubhon siya." [More shortness of breath ifhe had a cough.]

SS478: "Mo undang siya ug dede kay moginhawa kay hangak siya." [She would stop in breastfeeding because she will catch her breath.]

Additionally, 6 out of 10 mothers verbalized that their children experienced recurrent cough.

SS7: "Kay gi ubo man akong anak ug naglisog ug ginhawa..." [Since my child had cough and difficulty in breathing...]

SS47: "Nahibong ko nga sige na siya ug ubo nga dili man unta namo siya igawas." [I was confused when my child always had a cough when in fact I did not expose her outside of the house.]

SS87: "Unya ubhon pud siya." [She also had a cough.]

SS123: "Kanang ubo mao jud na kasagaran sa akong anak unya mahilantan siya." [She often had a cough then fever.]

SS234: "Ang ako lang nabantayan sa akong anak kay dali siya ubhon." [I noticed that she easily got cough.]

SS315: “...unya mag ubo siya pirme.” [... and had acough.]

In addition, 6 out of 10 mothers verbalized that their children had a weak immune system.

SS5: "Akong nabantayan sa akong anak kay dali siya matapdan ug sakit." [I noticed that my child easily got sick.]

SS45: "Sa wala pa siya mahibaw-i nga naay PDA kay magsige siya ug kasakit ato." [Before she was diagnosed of PDA, she was always sick.]

SS86: "Sige siya kasakit ato nga wala pa siya madiagnose ug PDA." [She was sickly before she was diagnosed with PDA.]

SS122: "Ako sad nabantayan kun naay ubhon kay dali kaayo siya matakdan." [I also noticed that she easily got infected of a person with cough.]

SS264: "Kato nga panahon kay prone kaayo akong 
anak magkasakit kay hinay siya ug immune system." [At that time, my child was prone to illness because of her weak immune system.]

SS315: "Sige man siya ug sakit sakit ato..." [He was always get sick...]

Due to the abnormal manifestation of their children the mothers were more distressed and decided for consultation with a doctor. The said physician then conducted an assessment and found out a distinct sign of a defect which is a characteristic machinery type of murmur called "Gibson's murmur" which may be heard using a stethoscope. This type of "murmur" is a sign of Patent Ductus Arteriosus (PDA) (Leifer, 2015). There were 6 out of 10 mothers who verbalized that the doctor informed them that a "murmur" was heard in the heart of their children. According to the mothers:

SS8: "Niana ang doctor nga naa siya'y madunggan nga "murmur" sa heart sa bata." [Then the doctor told me that he heard a "murmur" in the child's heart.]

SS124: "Gipaminaw sa doctor ang heartbeat sa bata ug naka-ingun siya nga naa daw "murmur" ang heart." [The doctor heard the child's heartbeat and said that there was a "murmur" in the heart.]

SS235: "Pag 8 months sa akong anak, naay usa ka doctor sa sentro nga ni ingun nako nga naa siya'y madunggan nga "murmur" sa heart sa akong anak." [When my child was 8 months, the doctor in the health center informed me that there was a "murmur" in the child's heart.]

SS316: "Pag 6 months sa akong anak, ni advise ang doctor nga ipa $2 D$ Echo akong anak kay naa daw "murmur." [When he was 6 months old, the doctor advised for $2 D$ Echo procedure because he heard a "murmur."]

SS465: "Naay possibility nga dili sa daw madischarge si baby kay na daw nadunggan nga "murmur" sa heart ang doctor." [There was a time when the nurse told me that there was a possibility that my baby would not be discharged because the doctor heard a "murmur" of her heart.]

SS513: "Didto nabantayan sa doctor nga naay "murmur" iyang heart." [The doctor noticed of the "murmur" in my child's heart.]

The doctors then referred the mothers to a pediatric cardiologist for further evaluation. The said pediatric cardiologist then conducted echocardiogram. To define exactly the type, treatment and prognosis of the heart problem, there is a need for thorough evaluation that may include signs, laboratory tests, chest x-rays, electrocardiograms (ECG) and echocardiography (Lázaro \& Pondé, 2017). Accurate diagnosis of patent ductus arteriosus requires echocardiography (Yapakçi et al., 2014). All the mothers verbalized that the 2D Echocardiogram with Doppler was the confirmatory test of their children with PDA.

SS9: "Pag-after ug 2D Echo nahibaw-an nga naay PDA akong anak." [After the 2D Echo, my child was diagnosed with PDA.]

SS40: "Nahibaw-an nako nga naa siya'y PDA after pagpa 2D Echo." [I knew she had a PDA after the 2D Echo Procedure.]

SS82: "Gi 2D echo siya ni doctor ug pagkahuman niana si doctor nga naa man ni siya'y abnormal between the heart and the lungs ug mao daw ang gitawag nga PDA." [The doctor conducted the $2 D$ Echo procedure and after the doctor told me that the child had an abnormal characteristic between the heart and lungs, and it was called PDA.]

SS127: "Nakahibalo ko nga naa siya'y PDA after ug 2D Echo." [I knew she had PDA after the 2D Echo.]

SS168: "Then pagpa check sa iyang heart kay gipa $2 D$ Echo akong anak then didto nakita nga PDA." [When he had check-up with his heart through 2D Echo, it was revealed that he had a PDA.]

SS238: "Paghuman ug 2D Echo sa akong anak nahibaw-an nga naa siya'y PDA." [After the $2 D$ Echo, my child was diagnosed with PDA.]

SS317: "Ang 2D Echo didto sa diagnostic center ug nagperform kay pedia cardio, ug mao after $2 D$ Echo nahibaw-an nga naa siya'y PDA." [The 2D Echo was conducted in a diagnostic center and performed by a pediatric cardiologist, then after it was known that he had a PDA.]

SS415: "Katong nahibaw-an nga naa siya'y PDA after $2 D$ Echo..." [That knowing she had a PDA after the 2D Echo...]

SS469: "After 3 weeks old ni baby kay nagpa 2D Echo mi ni baby ug sa $2 D$ Echo jud na confirmed nga PDA ang sakit ni baby." [When my baby was 3 weeks old, she underwent the $2 D$ Echo and it was the $2 D$ Echo that confirmed that it was PDA, my baby's illness.]

SS514: "Pag after 2D Echo didto nahibaw-an nga naay PDA akong baby." [After the 2D Echo, my child was known with aPDA.] 


\section{Sub-theme 2: Denial and Sadness}

The mothers refused to admit the truth or reality about their children's PDA after the confirmatory test, this is Denial (Merriam-Webster Dictionary, 2018). The mothers were shocked as this diagnosis of a heart defect is totally unexpected. (Bruce, Lilja \& Sundin, 2014). As such, 8 out of 10 mothers verbalized that they were in denial of their children's diagnosis. According to them:

SS4: "Naglisod ko pagdawat nga ingun ana akong anak pagkahibalo nako." [I had difficulty in accepting the situation of my child when I knew it.]

SS85: “...dili jud ko makatuo sa sakit sa akong anak." [...I can't believe that my child had that disease.]

SS131: “...pagkahibalo nako nga naa siya'y PDA ug dili jud ko makadawat ba." [... when I knew that she had aPDA and I couldn't accept it.]

SS170: "At that time dili ko katuo nga naay PDA akong anak." [At that time, I couldn't believe that my child had a PDA.]

SS256: "Kalit siya pagkahitabo nako unya lisod nako dawaton." [It was a sudden incident and I had difficulty in accepting it.]

SS410: "Wala ko magdahum nga naay diperensya sa heart akong anak ug dili ko makatuo." [I didn't expect her to have a heart disease and I couldn't believe it.]

SS468: "Dili jud ko katuo nga naay buslot sa heart si baby." [I couldn't believe that my baby had a hole in the heart.]

SS518: "Dili ko makatuo nga naa siya'y PDA kay normal man jud siya pagkababy." [I couldn't believe that she had a PDA because she was a normal baby.]

Aside from denial, the mothers expressed grief or unhappiness called Sadness (Merriam-Webster Dictionary, 2018). They cried with hopelessness in life, discomfort, and confusion (Sabzevari et al., 2016). All the mothers verbalized their sadness upon knowing their children's PDA. According to them:

SS3: "Siyempre nagguol ko, naghilak ko pagkahibalo nako nga naay PDA akong anak." [Of course I was sad, I cried when I knew that my child had a PDA.]

SS51: "Sige ko ug hilak pagkahibalo nako nga naa siya'y PDA." [I always cry when I knew that my child hadPDA.]
SS91: "Pagkahibawo nako nga naa siya'y PDA kay nagguol ko uy." [When I knew that she had a PDA, I was sad.]

SS135: "Guol kaayo ko pagkabalo nako nga naa siya'y PDA unya wala jud ko kabalo ug unsa akong buhaton." [I was so sad when I knew that she had a PDA and I didn't know what to do.]

SS194: "Nagguol jud ko pagkahibalo nako nga naa'y PDA akong baby ug nakahilak jud ko." [I felt sad when I knew that my baby had aPDA and I cried.]

SS254: "Nagguol ko nga naa siya'y PDA kay mura ko ug gidat-ugan nga kalit pagkahitabo." [I felt sad when she had a PDA and I felt that I was pushed very hard with an unexpected incident.]

SS330: "Guol jud akong gibati pag kabalo nako nga naay PDA akong anak." [I felt sad when I knew that my child had a PDA.]

SS418: "Pirte jud nakong hilak katong bag-o pako nakabalo nga naay PDA akong anak." [I cried a lot when I first knew that my child had a PDA.]

SS470: "Nagsugod ko ug kaguol pagkahibalo nako nga naa'y PDA si baby." [I started to be sad when I knew that my baby had a PDA.]

SS519: "Pagfirst nako nakahibalo nga naa siya'y PDA kay nagguol ko." [When I first knew she had a PDA, I was sad.]

\section{Sub-theme 3: Financial challenge: a difficult task}

The cost of operation was the main challenge of the mothers after their children were diagnosed with PDA. It was a difficult task for them since the operation was expensive. Sabzevari et al. (2016) stated that this disease usually increases the expenses of the family, hospitalizations, medications and frequent treatments increases the need of the family. Thus, all mothers verbalized that they were challenged in terms of financial expenses. According to them:

SS28: "Kay financially, pila ra baya ang income ug muhisgot ka ug PDA operation dako baya ug gasto." [Financially, my income could not afford speaking of the PDA operation because it was expensive.]

SS66: "Nachallenge ko sa financial atong giingnan ko nga pa operahan akong anak." [I was financially challenged when I learnt that my child needs to be operated.]

SS111: "Ang challenge kay kwarta para sa 
operation sa akong anak." [The challenge was money for my child's operation.]

SS137: "Basta operation baya sa heart kay mahal baya ug gasto ug asa ko mangita ug kwarta ani." [When it comes to heart operation, it was expensive and where can Ifind such money.]

SS181: "Mao to gi ingnan ko nga kinahanglan na operahan ug kailangan ug 300,000 pesos ug wala ko ana nga kwarta." [Then the doctor told me that the child needs an operation that would cost 300,000 pesos and I didn't have that money.]

SS286: "Ang financial lang jud sa opera ang lisod." [The financial aspect in the operation was difficult.]

SS331: "Naka ana ko kun unsaon nako nga kuwang baya mi sa financial." [I told myself what I would do since we were financially backward.]

SS434: "Ang akong kalisud kay financial kay wala baya'y klarong trabaho akong pares." [I have a financial difficulty because my partner didn't have a stablejob.]

SS482: "Gimention ni doc nga 300,000 pesos ang magasto sa operation kun PDA Occlusion which is mahal." [It was mentioned by the doctor that the operation costs 300,000 pesos if we choose PDA Occlusion, which is expensive.]

SS556: "Ang challenge kay financially kay naa siya'y maintenance tambal before sa operation, ang gasto sa PDA device ug operation." [My challenge was financial due to the medicines before operation, the cost of a PDA device and operation.]

\section{Sub-theme 4: Caring challenges}

Being a primary caregiver of a child with PDA, is a challenge for a mother. Bruce et al. (2013) stated that mothers can rarely prioritize their own interests and social activities and one reason for this limitation is the feeling of fatigue that occurs as a result of managing and structuring every activity around the child. A study of Sabzevari et al. (2016) showed that when the mother must be at the service of a sick child all the time, doing her indoor and outdoor responsibilities will be very difficult and painful for her.

There were 6 out of 10 mothers who verbalized that their children's check-up with a doctor in the hospital was a challenge for them. According to the mothers:

SS68: "Hapit nalang dili makakaon kay sige ug balik balik sa doctor ug pa check-up sa bata. " [I almost can't eat because I always went to the doctor for my child's check-up.]

SS96: "Grabe naman gud kay sige nako ug balik balik sa hospital kay sige siya ug kasakit." [It was so intense because I always go to the hospital since she always gets sick.]

SS155: "Ang kakapoy nga magsige ug lakaw unya magdala sa bata kana gani adto sa hospital unya uli unya ugma na sad balik sa hospital unya naay karga nga bata." [The burden I encountered was bringing the child to the hospital then back home then the next day we go back again to the hospital.]

SS263: "Unya ang kakapoy pa jud kay pila ka kaadlaw magstay sa syudad para sa check-up sa bata." [It was tiring because you need to stay for several days in the city for my child's check-up.]

SS380: "Unya inig pa check up nako niya, magdala pako niya unya magdala pako sa iyang manghud unya magjeep ra baya mi." [Then during follow-up check up, I would bring him and his younger brother then we take ajeepneyride.]

SS420: "After sa 2D Echo kay sige ko ug adto sa government hospital para check-up sa akong anak before sa operation." [After the 2D Echo, I always go to a government hospital for the check-up of my child before the operation.]

Furthermore, 6 out of 10 mothers verbalized that their children's medicine intake before operation was another challenge during care. According to them:

SS10: "Dili jud lalim kay naa man ipa inom niya nga tambal sa wala pa operahi ug ang pagmonitor sa bata." [It was not easy because the child needs to take medications and be monitored.]

SS67: "Nachallenge ko sa pagpa inom sa tambal sa akong anak katong sige siya ug kasakit." [I was challenged to let my child take the medicine when she always gets sick.]

SS163: "Kapuyan pud ko magpa inom niya sa tambal before sa operation kay dili siya ganahan sa tambal." [I also get tired to let my child take the medicine before the operation since she didn't like the medicine.]

SS267: "Kapoy pud kay magpa inom pa ko sa maintenance tambal sa bata nga giresita sa doctor sa wala pa siya ma operahan." [It was tiring because I need to let my child take the maintenance medicine 
before the operation.]

SS384: "Unya kapoy pud kay kinahanglan nga magpa-inom sa maintenance nga tambal sa bata." [Then it was tiring since I need to let my child take the medication.]

SS487: "Kapoy pud inig painom ni baby sa medicines nga giresita ni doc before operation." [It was tiring to let my baby take the medicines as prescribed by the doctor before the operation.]

Aside from that, 6 out of 10 mothers verbalized that they did not get enough sleep while providing care to their children.

SS1: "Lahi ra gyud sa una nga kanang wala pa na operahi akong anak kay wala koy tarung katulog. " [It was different before when my child had not been into operation because I didn't have enough sleep.]

SS77: "Sa una wala koy tarung katulog kay sige ug kasakit akong anak." [Before, I didn't have enough sleep since my child was always sick.]

SS93: "Sa wala pa operahi kay kapoy kayo ug wala koy tarung katulog kay kun magpakaon ka kay dapat barug, magpa inum ka kinahanglan kay barug, naay time interval sa pagpakaon, $i$-slant jud nimo siya ug dili pwede pakatulgon nga bag ong totoy ug bag ong kaon." [Before she underwent operation, it was so tiring and I didn't have enough sleep because if you fed her it had to be in an upright position, let her drink in an upright position, a time interval in feeding her, she needed to be in a slanting position, you will not allow the child to sleep every after breastfeeding.]

SS197: "Tapos kulang ko sa katulog pagsige ug punas sa singot ni baby." [I also had lack of sleep because I always wipe the sweat of my baby.]

SS268: "Grabe na jud akong pag-atiman sa akong anak kay wala koy tarung katulog sa sige ug trapo sa iyang singot." [It was very hard for me to take care of my child because I didn't have enough sleep since I always wipe my child's sweat.]

SS446: "Bahala ug bation kug kakapoy ug walay tarung tulog, atimanun gihapon nako akong mga anak ug paeskwelahon." [Though I felt tired and didn't have enough sleep, I still take care of my children and send them to school.]

SS503: "Wala jud koy tarung tulog kay hangak siya ug dili continuous magbreastfeed." [I didn't have enough sleep because she had shortness of breath and couldn't continuously breastfeed.]

\section{Clustered Theme 2: Ambivalence: a mixed feeling during operation}

The mothers felt contradictory feelings simultaneously known as ambivalence (MerriamWebster Dictionary, 2018). Both negative and positive feeling is a mixed emotion felt by the mothers during their children's operation. A feeling of anxiety was felt by the mothers due to the unknown outcome of their children's operation. Moreover, 7 out of 10 mothers verbalized that they experienced an ambivalent feeling during their children's operation. According to them:

SS17: "During sa operation kay lain-lain akong gibati kay nalipay ko na ma-operahan ang bata and nakuyawan ko sa mahitabo sa akong anak human ug opera. " [During the operation, I felt different emotions because I'm happy that my child would be operated but I felt anxious of the outcome of my child's operation.]

SS61: "During sa operation kay nakuyawan ko ug nalipay ko nga ma operahan na jud siya." [During the operation, I was anxious and happy that my child would be operated.]

SS147: "Nalipay ko kay ma operahan na siya dayun nakulbaan ko kay wala ko kabalo kun unsay result sa opera." [I was happy because finally my child would be operated but I was anxious because I didn't know the result of the operation.]

SS274: "Sagul jud akong gibati during sa opera sa akong anak kay nakuyawan ko sa mahitabo niya unya nalipay pud ko kay nahitabo na jud akong gipaabot nga ma-operahan siya." [I experienced mixed emotions during my child's operation because I was anxious for my child and I was happy since finally my child would be operated.]

SS358: "Kato nga adlaw sa opera kay sagul akong gibati kay nalipay ko kay maoperahan na jud akong anak pero nakuyawan ko sa mahitabo inig human ug opera. " [That day of the operation I had mixed feelings because I was happy that my child would be operated but I was also anxious of the operation's outcome.]

SS425: "Katong padulong siya for operation, wala ko kasabot sa akong gibati kay nalipay ko nga ma operahan na pero nakuyawan man pud ko." [On the day of the operation, I felt mixed emotions like I was happy for my baby's operation yet I was anxious.]

SS541: "Pagdala sa akong anak sa cath lab kay mixed emotions akong gibati kay kana bang nalipay ko kay ma operahan na pero grabe pud akong kulba." [When my child was brought to the catheterization lab, 
Ifelt mixed emotions since I was happy that my child be operated but I was also very anxious.]

Clustered Theme 3: Alleviation: a mother's relief after operation

The mothers felt relieved or free from burden known as alleviation (Merriam-Webster Dictionary, 2018). In the countless efforts showed by the mothers to their children, finally they were relieved after their children's operation. After agony, a feeling of alleviation was felt by the mothers. All the mothers verbalized that they were happy and relieved after the successful operation of their children. According to them:

SS18: "After sa operation gibati nako ang tumang kalipay kay successful ang operation." [After the operation, I felt very happy because the operation was successful.]

SS62: "After sa operation kay mura jud ko ug gi ibtan sa tunok." [After the operation, I felt lifted with thorns in my heart.]

SS104: "Ug after sa operation nalipay jud ko." [And after the operation, I was so happy.]

SS148: "Paghuman ug opera kay siyempre nalipay." [After the operation I was happy.]

SS204: "Paghuman sa operation kay nahayahay akong pamati." [After the operation, Ifelt so good.]

SS280: "Pirte jud nako hilak sa akong kalipay!" [I really cried for happiness!]

SS362: "Paghuman sa opera kay lipay kaayo ko!" [After the operation, I was very happy!]

SS433: "Nalipay ko kay sa pirte nako pangita ug hinabang sa una maskin buntis ko kay nalampos jud nako." [I was happy because, I successfully made it.]

SS499: "Relief jud siya for me after sa operation." [For me, it was very relieving after the operation.]

SS547: "Nawad-an na jud ko ug burden after sa operation sa akong anak." [I was burden free after my child's operation.]

Moreover, 7 out of 10 mothers verbalized the better growth and development of their children after operation. According to them:

SS31: "Pasalamat jud ko nga si inday ok na jud siya ug nigain na siya ug weight." [I am thankful for my child as she gained weight.]

SS75: "Dako jud ug kausaban sa wala pa siya na operahan ug after siya na operahan kay karon makita na ang pagtubo sa bata." [There was a big difference when she was not operated and after the operation because now you can see the child's growth and development.]

SS106: "Ang usa jud na usab after operation kay ang gi dak-on sa bata which is gamay siya before operation and after operation kay nidako jud siya." [One thing that changed after the operation, was the built of the child which was small before operation and after operation she grew a lot.]

SS310: "Ni gain na siya ug weight." [Then she gained weight.]

SS371: "Dayun nigain na iyang weight." [Inoticed that he gained weight.]

SS463: "Nidako na siya ug makita na iyang growth development." [She had a good growth development.]

SS548: "Dako jud ug kausaban after sa procedure sa akong anak kay nanambok jud dayun siya." [There was great change after the operation of my baby because she gained weight.]

Furthermore, 6 out of 10 mothers verbalized that their children didn't experience shortness of breath after operation.

SS19: "Murag naibtan ug tunok kay wala na siya naglisod ug ginhawa." [Ifelt lifted with thorns because she didn't experience shortness of breath.]

SS76: "Karun kay dili na jud siya maglisod ug ginhawa ba." [Now, my child didn't experience shortness of breath.]

SS206: "After operation, kay wala na siya naghangos..." [After operation, my child didn't experience shortness of breath...]

SS312: "Wala napud to iyang lisod nga pag ginhawa. " [She didn't experience shortnes of breath.]

SS374: "Wala najud siya maghangak." [He didn't experience shortness of breath.]

SS501: "Dili na hangak si baby inig breastfeed nakuniya." [My baby didn't have any shortness of breath during breastfeeding.]

In addition, 6 out of 10 mothers verbalized that their children didn't experience cough after operation.

SS20: "Wala na nag ubo akong anak..." [My child didn't experience cough...]

SS74: "Wala na jud to iyang gibati sa una ug wala 
na sad siya nag ubo ubo." [My child didn't feel the symptoms before and she did not have cough.]

SS103: "After sa operation, wala na jud gi ubo akong anak." [After the operation, my child didn't experience cough.]

SS149: "Pasalamat jud ko nga wala na gi ubo akong anak." [I was thankful that my child didn't experience cough.]

SS311: "Wala na siya gi-ubo." [She didn't experience cough.]

SS372: "Dili na siya ubhon." [He didn't experience cough.]

Additionally, 6 out of 10 mothers verbalized that their children had good immune response after operation.

SS21: "Wala napud nagkasakit akong anak." [She wasn't sick anymore.]

SS73: "After sa opera, wala na jud nagkasakit akong anak." [After the operation, my child didn't experience being sick.]

SS110: "Nagpasalamat pud ko nga wala na siya nagkasakit." [I was also thankful that she didn't experience being sick.]

SS162: "Karon kay makita na ang progress sa bata kay wala na jud siya nagkasakit." [Now, the child's progress can be seen since she didn't experience being sick.]

SS309: "After one-month nakabantay ko nga maayo na jud siya kay wala na siya nasakit." [After one month, I noticed her to be well because she didn't experience being ill.]

SS373: "Tapos wala na siya magkasakit." [Then he wasn't sick anymore.]

\section{Clustered Theme 4: Altruism: a selfless love}

Altruism is defined as giving up desires, wishes, wants, and valuables for the sake of something, achieving something with much effort and resources and focusing on helping people without expecting anything in return (Yildirim, 2016). Thus, the mother exhibits a devotion for the welfare of her child known as altruism (Merriam-Webster Dictionary, 2018). Quaye (2011) stated that mothers are the main person in the maintenance of family life therefore mothers are important to their families since child raising responsibilities are part of their roles. In the study, all the mothers verbalized their description of a mother based on their lived experience. According to the mothers:
SS24: “Ang usa ka inahan para nako kay kanang naay pag-antos sa pamilya kay naa jud na ang pagsuway." [A mother for me would sacrifice for her family because there are challenges.]

SS72 "Base sa akong naagian, ang usa ka inahan kay naay kalipay ug kalisud." [In my experience, a mother would encounter both happiness and difficulties.]

SS115: "Ang akong madescribe sa akong kaugalingon isip inahan kay buhaton nimo tanan ba maskin nagkalisod." [I described myself as a mother where I can do everything even though it was difficult.]

SS159: "Isip usa ka inahan kay sagul jud imung bation kay naay kasakit naay kalipay." [As a mother, you would encounter mixed emotions such as sadness and happiness.]

SS221: "Para nako ang usa ka mama kay imung buhaton ang tanan para sa imong anak." [For me a mother will do everything for the child.]

SS300: "First time mom man jud ko so base sa akong kaagi naka ana ko nga bahala wala koy kaon basta mauna lang jud akong anak." [I'm a first-time mom and based on my experience I could say that even though I didn't have anything to eat, I prioritize my child.]

SS396: "Ang usa ka inahan kay dili jud sayon labina kun full time mom ka." [Motherhood isn't easy especially ifyou are a full-time mom.]

SS451: "Ang inahan dili lalim kun naa kay anak nga naay PDA." [It was not easy for a mother to have a child with PDA.]

SS508: "A mother for me kay bestfriend sa anak kay dapat nimo maclose imong anak." [A mother for me is like a bestfriend to her child because you need to be close to her.]

SS566: "Para nako ang mother dapat always strong jud kay mao baya ang ilaw ng tahanan." [For me, a mother should be strong because she is the light of the house.]

Moreover, all the mothers verbalized their altruistic love for their children and family. According to them:

SS25: "Kinahanglan nga as a mother andam ka modawat bisag unsa pa ang mahitabo, kasakit man o kalipay sa pamilya ang mahitabo." [It is important as a mother that you are ready to accept no matter what happens, whether it is sadness or happiness in the family.] 
SS70: "Akong strength kay gilig-on ang kaugalingon para sa akong anak." [My strength is I remain strong for my child.]

SS116: "Tanan tanan imo jud ihatag ug buhaton para sa imong anak maskin lisod." [I will do everything for my child even though it was hard.]

SS152: "Naa jud ang sakripisyo nimo para sa imung anak ug imung buhaton ang tanan para sa imung anak." [You would sacrifice for the betterment of your child and you would do everything for her.]

SS222: "Sa akong case ako gi give-up akong career para sa akong anak kay dili nako kaya ihatag akong obligasyon as a mother sa uban." [In my case, I gave up my career for my child because I couldn't give to anybody my obligation as a mother.]

SS302: "Isip inahan maka ana ko ba kun pwede palang ang sakit sa akong anak ari nalang nako kay maka agwanta pako." [As a mother, I could say that if it is possible if the disease of my child would be transferred to me since I can endure it.]

SS393: "Ang akong strong point isip inahan kay mangita ko ug paagi nga maluwas akong anak." [My strong point as a mother was that I always find a way to save my child.]

SS446: "Bahala ug bation kug kakapoy ug walay tarung katulog, atimanun gihapon nako akong mga anak ug paeskwelahon." [Though I felt tired and didn't have enough sleep, I still take care of my children and send them to school.

SS509: "A mother for me also kay maoy mo provide ug care ug mo support sa anak." [A mother for me would provide care and support to her child.]

SS568: "As a mother dapat strong ka ug dili mawad-an ug faith labina para sa imung anak." [As a mother, you need to be strong and never lose faith especially for your child.]

Despite their children's health condition, 6 out of 10 mothers verbalized that they remain positive amidst the PDA of their children. According to them:

SS23: Para nako dili jud ko mother nga hopeless kay para nako tanan problema kay naay solusyon." [For me, as mother I do not lose hope because for me all problems have solutions.]

SS156: "Pero ako sad gi huna huna nga asa ra man unya ni ba kun ma-operahan na ang bata." [I thought that if my child would be operated, all my sacrifices would be worthy.]
SS223: "Naka-ana ko nga nagka PDA man akong anak so dapat kayahon jud nako." [I said to myself that since my child had PDA so I should tackle this.]

SS273: "Kay nakita nako nga strong akong anak ako sad gipakita niya nga strong ko ug dili mawad-an ug paglaum para niya." [When I saw that my child was strong, I also let her see that I'm strong and I will not lose hope for her.]

SS504: "Nahandle naku akong challenge by being positive ra jud pirme." [I handled my challenge by being positive always.]

SS562: "As a mother, ako jud gistrong akong self emotionally sa PDA situation sa akong anak." [As a mother, I made myself strong emotionally in the PDA situation of my child.]

\section{Clustered Theme 5: Adaptation: internal and external support}

The mothers were able to adjust in an environmental condition known as adaptation (Merriam-Webster Dictionary, 2018). In the case of the mothers, they found prayer as the most powerful key in the adaptation of an adversity. Moreover, the Non-Governmental Organization in our country aided the mothers in the financial cost of operation. Additionally, the support of each family member by means of communication can ease the mother's burden. Sira et al. (2014) stated that individuals relying on emotion-focused coping, resolve their stress by changing their thought and feelings about the situation through discussions with others and building a strong relationship. Moreover, the nurses provide support to the mothers by means of encouraging them and providing them knowledge about PDA.

\section{Sub-theme 1: Prayer: the powerful key to coping}

Prayer to God is a universal coping in terms of adversity in each individual. Sira et al. (2014) stated that spirituality is important while coping with stress related to their child's illness, and often accept their situation as a result of their belief in a higher power. Thus, the mothers seek religious help from God as a creator and provider in times of adversity. All the mothers verbalized that prayer was their source of coping at the time of adverse situation of their children with PDA. According to them:

SS13: "Akong gihimo first kay prayer kay dili nako makaya kun walay pagsalig sa Ginoo." [The first thing I did was to pray because I didn't think that I can do it if I don't trust God.]

SS69: "Sa katong panahona sa Ginoo jud ko 
nikapit ug nisampit jud ko niya." [At that time, I lifted it to God, and I called Him.]

SS117: "Kun magkalisod, the most powerful is prayer jud." [In times of difficulties, prayer is the most powerful thing to do.]

SS136: "Mao to ako lang jud gi ampo sa Ginoo." [That's why I always pray to God.]

SS214: "Daan man jud ko sa una nga kun naa'y problem kay sampit dayon ko sa Ginoo." [Since before, it is my attitude that when I had a problem, I called for God's help.]

SS285: “Ang akong kalisod kay ako ra gi ampo sa Ginoo." [I prayed all my difficulties to God.]

SS389: "Katong lisod akong kahimtang magsige ra jud ko ug ampo ato." [Those difficulties, I always prayed.]

SS430: "Maskin dili ko sige ug simba, sige jud ko ug ampo atong panahona nga maayo unta ang iyang operation." [Despite that I will not go to church regularly, I always prayed that time that hopefully the operation would be successful.]

SS494: "Nagsige jud ko ug pray ato nga naa untay miracle nga moclose iyang PDA." [I always prayed that there would be a miracle that closes her PDA.]

SS561: "Na overcome nako akong challenge through prayers pud kay maoy nakapa lig-on nako as a mom." [I also overcome my challenge through prayers because it made me a strong mother.]

\section{Sub-theme 2: Financial support}

Modern science and technology evolved into the creation of device and equipments to be used for the better chance of survival of mankind in the cardiac catheterization laboratory. As such, operation is highly expensive and the cost for the operation matters to the mothers since they understand the necessity of operation in their children's health. The financial support of Non-Governmental Organizations in our country is of big help to the mothers. Additionally, the support of private and government hospitals for charity case helped the mothers lessen the cost of operation. All the mothers verbalized that they cope in their financial difficulty by means of financial support she received from other people. According to the mothers:

SS29: "Pasalamat lang sad ko nga naay doctor nga nitabang namo financially." [I was thankful that a doctor helped us financially.]
SS42: "Mao to nakadecide ang igsuon sa akong partner nga inig abot ug 3 years old sa bata, andaman niya ug kwarta para ma-operahan akong anak." [Then the sister of my partner decided that once the child reached 3 years old, she would provide money for the child to be operated.]

SS119: "Dako pud ug natabang akong bana sa financial." [My husband helped me a lot in terms of financial.]

SS141: "Sa ikaduha nga chance namo kay naay nisponsor nga Korean gikan sa NGO." [In our second chance, there was a Korean sponsor from a NonGovernmental Organization.]

SS183: "Maayo gani nisugot ang company sa akong husband nga mangutang ug nangutang akong bana para opera sa among anak." [We were lucky that the company of my husband allow him to lend money, so my hus band lend the money for our child's operation.]

Ss272: "Maayo gani nalibre ang hospital bill tungud ni apply ko sa charity ug ang device nalang maoy palitun." [It was good that the hospital bill was free due to the charity I applied, and I bought the device only.]

SS356: "Inig admit na sa bata hangtud sa opera kay ang foundation na ang mosponsor ug nagpasalamat jud ko." [When the child would be admitted for the operation, the foundation sponsored, and I was thankful for that.]

SS424: "Dako jud akong pasalamat nga palitun sa igsuon sa akong partner ang PDA device para maayo iyang pag-umangkon." [A big thanks that the sibling of my partner will buy the PDA device for the treatment of his niece.]

Ss 481: "Akong parents ug parents sa akong partner kaynag-amot na sa ibayad sa operation. " [My parents and the parents of my partner shared for the payment of operation.]

Ss559: "Since ni apply ko ug charity sa private hospital nakasave ko ug around 150,000 pesos. " [Since I applied for charity in a private hospital, I saved around 150,000 pesos.]

\section{Sub-theme 3: Social support}

The social support needed by the mothers is highly essential in times of difficulties. They need someone to comfort them in order to ease the burden they felt in relation to their child's PDA. Bruce, Lilja \& Sundin. (2014) stated that social support is very important for 
mothers who are in crisis and the examples of contacts who can provide support by listening and conversing with them are the spouses, children, grandparents, next of kin, friends and colleagues. There were 8 out of 10 mothers who verbalized that their husband or partner support them emotionally in times of crisis. According to them:

SS39: "Nakatabang sad akong husband sa emotional support." [My husband also helped me emotionally.]

Ss 78: "Akong partner ang nagsige ug kuyog nako inig pa check-up sa akong anak." [My partner always accompanies me and my child during check-up.]

Ss 118: "Ang akong bana ang nihatag nako ug emotional support kay siya ang magsige ug ingon nga dili ta mawad-an ug paglaum ug mangita ta ug paagi nga matambalan atong anak." [My husband supported me emotionally by always telling me not to lose hope and we would find a way for our child be treated.]

SS165: "Ako pud partner ang sige ug sulti nga dili ko magguol sa kahimtang sa among anak." [My partner also reminded me to not be sad of our child's condition.]

SS297: "Ang ako nga pares maoy rason nga na overcome nako ang challenge kay magsige man ko ug tawag niya ug mo advice siya ug maayo nga buhaton." [My partner was the reason why I overcome my challenges because I always call him. Then he advised me ofgoodways.]

SS404: "Akong bana ang nag encourage nako nga dapat akong lig-unon akong kaugalingon para sa among anak." [My husband always encourages me to be strong for our child.]

SS459: "Sige sad ug tambag akong partner nako nga dili magsige ug kaguol sa sitwasyon sa among anak." [My partner always advice me not to be sad with our child's situation.]

SS565: "Maayo gani kay akong bana mosupport nako emotionally and through decision making in times mafrustrated ko." [It was good that my husband supported me emotionally and through decision making in times Ifeel frustrated.]

Moreover, 6 out of 10 mothers verbalized that their family and friends support them emotionally. According to them:

SS30: "Gitambagan ko sa akong kaila nga doctor nga ipa charity akong anak sa operation para makasave ko sa gasto sa operation." [A doctor whom I knew advised me to apply my child for charity case operation so that I can save in the cost of operation.]

SS158: "Akong parents ang nitambag nako nga pa operahan ang bata ug dili mahadlok." [My parents advised me that the child must undergo an operation and I should not be afraid.]

SS402: "Akong lain nga paagi nga nakacope ko kay sa akong mga kaila nga nakahatag naku ug referral kun kinsay makatabang naku bahin sa akong anak." [My other way of coping up was with friends who provided me with referrals of whom that can help me regarding my child.]

SS427: "Ang akong maguwang man ang magsige ug sulti nga dili ko mag kuyaw-kuyaw ug mag ampo jud ko sa Ginoo kay ang Ginoo ra ang makatabang nato." [It was my elder sister who always tell me that I will not be afraid, and I will pray to God because it is Him that canhelpme.]

SS480: "Niana ang both parents namu sa ako partner nga dapat next month na for operation si baby ug dili na mowait sa November nga free operation." [Both our parents told me and my partner that the operation for the baby would be next month and not to wait for the free operation in November.]

SS544: "Naa sad ako mga kaila nga nisupport nako emotionally." [I also have with me my friends to support me emotionally.]

Finally, 5 out of 10 mothers verbalized that the nurses support them. According to the mothers.

SS120: "Ang nurses naka encourage nako nga dili mawad-an ug paglaum." [The nurses encouraged me to not lose hope.]

SS166: "Naka-encourage ang nurses nako nga dili mawad-an ug paglaum." [The nurses encouraged me to not lose hope.]

SS314: "Nagpasalamat jud ko ato nga nurse kay gitarung ko ug explain sa PDA ug mao to na encourage ko mapa-operahan akong anak para maluwas siya. " [I thanked that nurse because she explained well to me about PDA and it encouraged me for my child's operation to save my child's life.]

SS405: "Ni encourage ang nurse sapediatric clinic nga dili magpawala sa paglaum kay daghan mi ug pareha ug kaso nga na operahan sa kadugayan ug paabot." [The nurse in the pediatric clinic encouraged me to not lose hope since there were many with the same 
case who was waiting for a longer time for the operation.]

SS462: "Ang nurse nakatabang ug tudlo naku kun unsa ang PDA." [The nurse helped me by teaching me about $P D A$.]

This study explored the lived experience of mothers as primary caregivers for their children with PDA. After comprehensive analysis, five clustered themes emerged namely: (1) Agony: a struggle before operation; (2) Ambivalence: a mixed feeling during operation; (3) Alleviation: a mother's relief after operation; (4) Altruism: a selfless love and (5) Adaptation: internal and external support.

Sub-themes also appeared from these clustered themes. The sub-themes in the first clustered theme include: Sub-theme 1: Fear of the unknown; Sub-theme 2: Denial and Sadness; Sub-theme 3: Financial challenge: a difficult task: Sub-theme 4: Caring challenges. In the fifth clustered theme include: Subtheme 1: Prayer: a powerful key to coping; Sub-theme 2: Financial support; and Sub-theme 3: Social support.

Agony described the challenges of the mothers before their children's operation. All the mothers described their challenges both emotionally and financially. They had difficulty in accepting the situation. Their feeling got more intense due to the expensive cost of operation to save their children's lives. Caring challenges also became apparent in relation to their children's manifestation.

Ambivalence described both positive and negative emotions felt by the mothers during their children's operation. They couldn't fathom the mixed emotions they experienced. They were happy of their children's operation since it could save their children's lives. However, a feeling of anxiety also existed due to the unknown outcome of the operation.

Alleviation described the mothers' relief after their children's operation. All the mothers were filled with joy due to the operation's successful outcome. They observed their children's good prognosis and the child did not encounter any health problem after the operation.

Altruism described the selfless love of the mothers to their children. All the mothers expressed their altruistic love by prioritizing their children above all else in the world. Despite the challenges they encountered, the mothers remained positive and strong for their children's betterment.
Adaptation described the mothers' adjustment amidst adversity. All the mothers described prayer as a powerful coping method in times of difficulties. Moreover, financial support from other people aided them to overcome their financial challenge. Lastly, the social support of their family, friends and nurses encouraged them to remain strong and not lose hope of their children's PDA.

According to Kübler-Ross's model, people experience five stages of reactions through denial, anger, bargaining, depression and acceptance. In the denial stage, the person may feel shocked and have a difficulty in understanding the reality of the situation (Holland, 2014). In this stage, it is important to comprehend that the person is not angry with the nurse or the family. The more enthusiastic the nurse is when she approaches the patient, the more she is going to get through to the patient (Kübler-Ross, Wessler \& Avioli, 1972). In this study, most of the mothers expressed denial upon their knowledge of their children's PDA.

Then disbelief can sometimes be replaced by feelings of anger characterized by feelings of bitterness and questioning God (Holland, 2014). The nurse must help the person express her anger, consequently, the person became more comfortable with the nurse (Kübler-Ross et al., 1972). In this study most mothers questioned God for the existence of their children's disease.

In the stage of bargaining, people attempt to "make a deal" with God which is accompanied by feelings of guilt. In the stage of depression, people experience feelings of despair, hopelessness and isolation (Holland, 2014). It is important for healthcare providers to help the person express her grief (Kübler-Ross et al., 1972). In this study most of the mothers felt depressed of their children's PDA.

Lastly, the acceptance stage is wherein the emotions may begin to stabilize and it is certainly a time of adjustment (Gregory, 2019). In this study, some mothers accepted their children's PDA.

\section{CONCLUSION}

\section{Implications}

Mothers as primary caregivers in caring for their children with PDA encountered different experiences before, during and after their children's operation as shown or reflected by the five clustered themes.

The nurses' emotional support helped some mothers overcome the challenge. Furthermore, the nurses' aided 
some mothers by providing information about PDA. However, only half of the KIs acknowledged the help of the nurses in terms of information dessimination and emotional support. Thus, it can be concluded that nurses must educate the community with crucial informations about PDA specifically on the essence of PDA operation in their children's lives.

\section{RECOMMENDATIONS}

Based on the findings of the study, the researcher recommends the following:
1. Nurses in all areas may consider the significance of health promotion to the public about PDA and opt to accept this vital role.

2. Nurses in the medical - surgical field may conduct a study about the lived experience of fathers having children with PDA.

3. Future researchers may consider a quantitative research instrument to measure the five clustered themes in this study.

\section{REFERENCES}

Alampay, L.P. \& Jocson, R.M. (2011). Attributions and Attitudes of Mothers and Fathers in the Philippines. Parenting, Science and Practice, 11(2-3), pp 163-176.

American Heart Association (2018). Patent Ductus Arteriosus (PDA). Retrieved from: https://www.heart.org/en/ health-topics/congenital-heart-defects/about-congenital-heart-defects/patent-ductus-arteriosus-pda

Amoozgar, H., Salehi, S., Farhadi, P., Edraki, M.R., Borzoee, M., Ajami, G., Cheriki, S. \& Mohammadi, H. (2016). Follow-Up Results of Device Occlusion of Patent Ductus Arteriosus. Iranian Journal of Pediatrics, 26(3), pp 3621.

Azhar, A.S., Abd El-Azim, A.A. \& Habib H.S. (2009). Transcatheter closure of patent ductus arteriosus: Evaluating the effect of the learning curve on the outcome. Annals of Pediatric Cardiology, 2(1), pp 36-40.

Barreto, T.S.M., Sakamoto, V.T.M., Magagnin, J.S., Coelho, D., Waterkemper, R. \& Canabarro, S.T. (2016). Experiences of parents of children with congenital heart disease: feelings and obstacles. Revista da Rede de Enfermagem do Nordeste, 17(1), pp 128-136.

Behjati-Ardakani, M., Behjati-Ardakani, M., Hosseini, S. \& Noori, N. (2013). Long-Term Results of Transcatheter Closure of Patent Ductus Arteriosus in Infants Using Amplatzer Duct Occluder. Iranian Journal of Pediatrics, 23(4), pp 411-416.

Bhatia, J. \& Dice, J.E. (2007). Patent Ductus Arteriosus: An Overview. Journal of Pediatric Pharmacology and Therapeutics, 12(3), pp 138-146.

Bruce, E., Lilja, C. \& Sundin, K. (2014). Mothers' lived experiences of support when living with young children with congenital heart defects. Journal for Specialists in Pediatric Nursing, 19(1), pp 54-67.

Cheng, D.D., Ortiz, E.E. \& Angtuaco, J.L. (2013). A single-blind randomized controlled trial comparing the efficacy of two doses of oral ibuprofen with intravenous indomethacin in terms of ductus arteriosus closure among premature infants with patent ductus arteriosus: A phase 2A clinical trial. Acta medica Philippina, 46(4), pp 51-55.

David-Padilla, C., David-Padilla, C., Dion-Berboso, A., Abadingo, M.E., Ty, K.S., Tumulak, M. R., Sur, A.L.D., Cutiongco-de la Paz, E.M. \& Cutiongco-de la Paz E.M. (2011).Occurrence of birth defects at the Philippine General Hospital: 2001-2010. Acta Medica Philippina, 45(4), pp 20-29.

Department of Health (2010). The 2010 Philippine Health Statistics. National Epidemiology Center. Statistics and Publication Section. Republic of the Philippines, Manila.

Dutta, S., Mihailovic, A., Benson, L., Kantor, P.F., Fitzgerald, P.G., Walton, J.M., Langer, J.C. \& Cameron, B.H. (2008). Thoracoscopic ligation versus coil occlusion for patent ductus arteriosus: a matched cohort study of outcomes and cost. Surgical Endoscopy. Surgical Endoscopy, 22(7), pp 1643-1648.

Engür, D., Deveci, M. \& Türkmen, M.K. (2016). Early Signs that predict later haemodynamically significant patent ductus arteriosus. Cardiology in the Young, 26(3), pp 439-445. 
Esfahanizadeh, J., Alizadeh, K., Tabari, M., Izanloo, A., Yaghobi, K. \& Najafi, M.N. (2017). Results of the Patent Ductus Arteriosus Closure Using the Video-Assisted Thoracoscopic Surgery. Iranian Journal of Pediatrics, 27 (3), pp 9916.

Franich-Ray, C., Bright, M.A., Anderson, V., Northam, E., Cochrane, A., Menahem, S. \& Jordan, B. Trauma reactions in mothers and fathers after their infant's cardiac surgery. Journal of Pediatric Psychology, 38(5), pp 494-505.

Gregory, C. (2019). The Five Stages of Grief: An Examination of the Kubler-Ross Model. PSYCOM. Retrieved from: https://www.psycom.net/depression.central.grief.html

Holland, J.M. (2014). Elisabeth Kübler-Ross. In book: The A-Z of death and dying: Social, medical, and cultural aspects, USA: ABC-CLIO, Editors: M. Brennan, pp 286-288.

Jannatdoust, A., Samadi, M., Yeganehdoust, S., Heydarzadeh, M., Alikhah, H., Piri, R. \& Naghavi-Behzad, M. (2014). Effects of intravenous indomethacin on reduction of symptomatic patent ductus arteriosus cases and decreasing the need for prolonged mechanical ventilation. Journal of Cardiovascular and Thoracic Research, 6(4), pp 257-259.

Jin, M., Liang, Y.M., Wang, X.F., Guo, B.J., Zheng, K., Gu, Y. \& Lyu, Z.Y. (2015). A Retrospective Study of 1,526 Cases of Transcatheter Occlusion of Patent Ductus Arteriosus. Chinese Medical Journal (English), 128(17), pp 22842289.

Jordan, B., Franich-Ray, C., Albert, N., Anderson, V., Northam, E., Cochrane, A. \& Menahem, S. (2014). Early motherinfant relationships after cardiac surgery in infancy. Archives of Disease in Childhood, 99(7), pp 641-645.

Kang, S.L., Samsudin, S., Kuruvilla, M., Dhelaria, A., Kent, S. \& Kelsall, W.A. (2013). Outcome of patent ductus arteriosus ligation in premature infants in the East of England: a prospective cohort study. Cardiology in the Young, 23(5), pp 711.

Kübler-Ross, E., Wessler, S. \& Avioli, L.V. (1972). On death and dying. JAMA, 221(2) pp 174-9.

Lan, S-F., Mu, P-F. \& Hsieh, K-S. (2007). Maternal experiences making a decision about heart surgery for their young children with congenital heart disease. Journal of Clinical Nursing, 16(12), pp 2323-2330.

Lázaro, C.P. \& Pondé, M.P. (2017). Narratives of mothers of children with autism spectrum disorders: focus on eating behavior. Trends in Psychiatry \& Psychotherapy, 39(3), pp 180-187.

Leifer, G. (2014). Introduction to Maternity and Pediatric Nursing. $7^{\text {th }}$ Edition, Saunders, United States of America.

Lumsden, M.R., Smith, D.M. \& Wittkowski, A. (2011). Coping in Parents of Children with Congenital Heart Disease: A Systematic Review and Meta-synthesis. Journal of Child and Family Studies, 28, pp 1736-1753.

Mellow, T. (2014). Bonding Experiences in Mothers of Infants with Severe Congenital Heart Disease. Thesis, University of London, London.

Merriam-Webster Dictionary (2018). Retrieved from: https://www.merriam-webster.com/dictionary/dictionary

Morrow, R., Rodriguez, A. \& King, N. (2015) Colaizzi's descriptive phenomenological method. The Psychologist, 28(8), pp 643-644.

Ofiaza, S.R., Marcelo, J., Ang, J. \& Rosario J.D. (2008). Outcome of patients with patent ductus arteriosus following surgery at the Philippine children's medical center from January 1998 to September 2006. Philippine Children's Medical Center Journal, 7(1), pp 57-61.

Philippine Statistics Authority (2004). Philippines - Vital Statistics Report on Deaths in the Philippines. Retrieved from: http://psa.gov.ph/psada/index.php/catalog/61/variable/V33

Polit, D.F. \& Beck, C.T. (2017). Essentials of Nursing Research: Appraising Evidence for Nursing Practice, Lippincott Williams \& Wilkins (LWW), Philadelphia.

Quaye, E. (2011). A Qualitative Study of the Everyday Life Experiences of Working Mothers and their Children in Accra, Ghana. Master Thesis, Institute of Psychology, Norwegian University of Science and Technology, Trondheim. 
Rathke, J., Menezes, H.S. \& Filho, R.I.R. (2014). Percutaneous Occlusion of Patent Ductus Arteriosus. Revista Brasileira de Cardiologia Invasiva, 22(4), pp 364-368.

Re, J., Dean, S \& Menahem, S. (2013). Infant cardiac surgery: mothers tell their story: a therapeutic experience. World Journal for Pediatric and Congenital Heart Surgery, 4(3), pp 278-285.

Sabzevari, S., Nematollahi, M., Mirzaei, T. \& Ravari,A. (2016). The Burden of Care: Mothers' Experiences of Children with Congenital Heart Disease. International Journal of Community Based Nursing \& Midwifery, 4(4), pp 374385 .

Sabzevari, S., Nematollahi, M., Mirzaei, T. \& Ravari, A. (2016). The Burden of Care: Mothers' Experiences of Children with Congenital Heart Disease. International Journal of Community Based Nursing \& Midwifery, 4(4), pp 374385.

Shosha, G.A. (2012). Employment of Colaizzi's Strategy in Descriptive Phenomenology: A Reflection of a Researcher. European Scientific Journal, 8(27).

Sira, N., Desai, P.P., Sullivan, K.J. \& Hannon, D.W. (2014). Coping Strategies in Mothers of Children with Heart Defects: ACloser Look into Spirituality and Internet Utilization. Journal of Social Service Research, 40(5).

Vallejos, L.M. (2015). Shattered: A heuristic self-search inquiry of one mother's journey to wholeness after a child's diagnosis of a potentially fatal congenital heart defect. ProQuest Dissertations Publishing, Saybrook University, California, USA.

Wei, H. (2015). The Experiences and Care Needs of Parents Whose Children are Born with Congenital Heart Disease. Dissertation, University of North Carolina, USA.

Yapakçı, E., Ecevit,A., Törer, B., Ince, D.A., Gökdemir, M., Gülcan, H. \& Tarcan, A. (2014). "Shunt index" can be used to predict clinically significant patent ductus arteriosus in premature neonates in early post-natal life. Cardiology in the Young, 24(4), pp 605-609.

Yıldırım, N. (2016). A Qualitative Analysis of Altruism (Selflessness): Views of Headmasters in Turkey. Journal of Education and Training Studies, 4(7), pp 82-91. 